UDC 316.4

LBC 60.54

\title{
TO A QUESTION OF SOCIAL DYNAMICS OF MIGRATION PROCESSES: WORLD AND RUSSIAN TRANSFORMATIONS
}

\author{
Naide S. Chernysheva \\ P.G. Demidov Yaroslavl State University, Yaroslavl, Russian Federation
}

\begin{abstract}
Annotation. The conceptual basis of the article is based on the following position: in modern conditions of innovative development of social systems (both international and national), the structure of migration processes loses the quality of the first position, migration becomes an integral part of its everyday life. The analysis of the social dynamics of migration processes, the strategies of migrants against the background of intensified risks and uncertainty in the receiving side is of particular relevance. The article presents statistical data of the Population Division of the UN international organization - a member of the Global Group on Migration, on the ratio of the number of migrants and the total population on a global scale, as well as the number and share of immigrants in gender and geographic context, a review of scientific foreign and domestic literature is carried out. which reflects the assessments of the features of horizontal movements in recent decades, describes the behavioral strategies of migrants, representatives of a foreign cultural environment. The author's theoretical multifactor model is presented, aimed at identifying promising areas for further research, reflecting the escalation of the impact of migration flows and the increase in the confrontational component as a counter strategy on the part of local, local communities in the course of intergroup interaction. The paper also provides statistical information on migration growth in the Russian Federation, interprets data from allRussian research projects collected by a survey method, and a sociological survey of residents of the Yaroslavl region, characterizing the situation of migrants, their involvement in the functioning of economic sectors in the views of Russian residents (at the regional level), as well as revealing the content of relations between local communities with visiting representatives of a foreign cultural environment. An empirical study made it possible to draw a conclusion about the ambivalent response of the residents of the receiving country to the volumes of migration flows and the strategies of migrants. The author substantiated that multiple scaling of the probability of the conflict component in the socio-cultural interaction of the receiving party and arriving representatives of a foreign cultural environment requires a comprehensive implementation of programs for mutual adaptation of the above-named entities, agreed by government agencies and non-profit organizations as parity partners.
\end{abstract}

Key words: migration processes, intensification, dynamics, intergroup interactions, local community, representative of a foreign cultural environment, behavioral strategies.

Citation. Chernysheva N.S. To a Question of Social Dynamics of Migration Processes: World and Russian Transformations. Logos et Praxis, 2021, vol. 20, no. 1, pp. 89-99.(in Russian). DOI: https://doi.org/10.15688/lp.jvolsu.2021.1.10

УДК 316.4

ББК 60.54

\section{К ВОПРОСУ О СОЦИАЛЬНОЙ ДИНАМИКЕ МИГРАЦИОННЫХ ПРОЦЕССОВ: МИРОВЫЕ И ОБЩЕРОССИЙСКИЕ ТРАНСФОРМАЦИИ}

\section{Наиде Сефтеровна Чернышева}

Ярославский государственный университет им. П.Г. Демидова, г. Ярославль, Российская Федерация

Аннотация. Концептуальная основа статьи базируется на следующем положении: на современном этапе инновационного развития общественных систем (как международных, так и национальных) структура миграционных процессов утрачивает качество исключительности, миграция становится неотъемлемым свойством повседневности. Особую актуальность приобретает анализ социальной динамики миграционных процессов, стратегий мигрантов на фоне интенсификации рисков и неопределенности в принимающей стороне. В статье 
представлены статистические данные Отдела народонаселения международной организации ООН - члена Глобальной группы по вопросам миграции, позволяющие судить о соотношении количества мигрантов и общей численности населения в мире, а также численности и доли иммигрантов в гендерном и региональном разрезе, проведен обзор научной зарубежной и отечественной литературы, в которой отражены особенности горизонтальных перемещений в последние десятилетия, охарактеризованы поведенческие стратегии мигрантов-представителей инокультурной среды. В работе приведена авторская теоретическая многофакторная модель, имеющая целью обозначить перспективные направления дальнейших исследований, отражающая эскалацию воздействия миграционных потоков на рост конфронтации как встречной стратегии со стороны локальных, местных сообществ в ходе межгруппового взаимодействия. В работе приводится статистическая информация о миграционном приросте в РФ, интерпретированы данные общероссийских исследовательских проектов, собранные методом опроса российских жителей, и социологического опроса жителей Ярославской области, характеризующие положение мигрантов, их вовлеченность в функционирование отраслей экономики, а также раскрывающие содержание отношений локального сообщества с приезжими-представителями инокультурной среды. Эмпирическое исследование позволило сделать вывод об амбивалентном реагировании жителей принимающей стороны на объемы миграционных потоков, стратегии мигрантов. Автором обосновано, что многократное масштабирование вероятности реализации конфликтной составляющей в социокультурном взаимодействии принимающей стороны и прибывающих представителей инокультурной среды требует комплексной реализации программ взаимной адаптации вышеназванных субъектов, согласованные государственные структурами и некоммерческими организациями в качестве паритетных партнеров.

Ключевые слова: миграционные процессы, интенсификация, динамика, межгрупповые взаимодействия, локальное сообщество, представитель инокультурной среды, поведенческие стратегии.

Цитирование. Чернышева Н. С. К вопросу о социальной динамике миграционных процессов: мировые и общероссийские трансформации // Logos et Praxis. - 2021. - T. 20, № 1. - C. 89-99. - DOI: https://doi.org/10.15688/lp.jvolsu.2021.1.10

Введение. Исторически воздействие миграционных процессов на жизнедеятельность граждан, социум, национальные государственные системы, мировое развитие является многофакторным. В текущий момент социальные, в том числе миграционные, процессы находятся под влиянием пандемии COVID-19, комплексно социально-экономические, политические, культурные, духовные и правовые последствия оценивать преждевременно, однако на данный момент сформировалось понимание, что посткороновирусный мировой порядок будет иным, также существенно меняются внутренние процессы национальных государств и миграционные потоки. Указанные обстоятельства детерминируют потребность осмысления миграционных процессов на различных этапах общественной жизни, тем более, что кардинальные трансформации в характере индивидуальных и групповых миграционных перемещений начали преобразовываться с начала XXI века.

Перечислим основные задачи настоящей работы, во-первых, анализ статистических данных, характеризующих динамику международной миграции по отношению к общей численности населения мира, а также структуру и направления миграционных перемеще- ний на межстрановом уровне (гендерный и региональный аспекты). Во-вторых, систематизация теоретических подходов о влиянии миграционных процессов на состояние современного социума. В-третьих, разработка авторской теоретической многофункциональной модели оценки перспектив международной миграции. В-четвертых, обсуждение результатов общероссийского и регионального эмпирических исследований, раскрывающих особенности взаимоотношений местных жителей (принимающего сообщества) с мигрантами (представителями инокультурной среды).

Реализация первой задачи данного исследования начиналась с сопоставления следующих данных: в 2019 г. численность международных мигрантов достигла 271,6 млн человек, что составило 3,5 \% от общей численности населения мира на середину 2019 г. [Total number of international... web]. По сравнению с началом XXI в., доля международных мигрантов от общей численности населения в мире возросла на $0,7 \%$ (так как в 2000 г. показатель был на уровне 173,6 млн - 2,8 \%) (табл. 1) [International migrant stock 2019... web].

При этом, в общей численности международных мигрантов количество женщинмигрантов в 2019 г. составило 130,1 млн (в до- 
лях $-47,9$ \%), что на 44,6 млн больше по сравнению с данными за 2000 г. (табл. 2).

Фиксируется интересная тенденция увеличение в абсолютных показателях числа женщин-мигрантов не совпадает с пропорциональными соотношениями в структуре миграционных перемещений по признаку «пол», так как доля женщин от общего количества международных мигрантов в 2019 г. достигла значения, которое на 1,3 п.п. ниже по сравнению с данными за 1990, 2000 гг. Число мужчин в структуре международной миграции к 2019 г., напротив, существенно выросло в абсолютных значениях на 53,5 млн по сравнению с 2000 г. и незначительно (на 1,3 п.п.) в относительных показателях.

Анализ межстрановых статистических данных позволяет зафиксировать возрастную структуру мигрантов в 2019 г.: 11,8 \% - доля международных мигрантов в возрасте от 65 лет и выше, 13,9 \% - количество международных мигрантов в возрасте 19 лет и младше. Соответственно, большинство мигрантов - люди трудоспособного возраста (20-64 лет) - 74,3 \% [Total number of international... web].

Практически треть всех мигрантов в 2019 г. едут в Азию (30,7 \% - 83,6 млн) либо в Европу (30,2 \% - 82,3 млн), четверть всех переселенцев отправляется в Америку $(25,9 \%$ 70,3 млн), тогда как практически каждый десятый мигрант выбирает Африку (9,8 \% 26,5 млн) и только 8,9 млн переселенцев - остановили выбор на Океании (3,3%) (табл. 3).
Вместе с тем структура миграционных перемещений в мире (1990, 2000, 2019 гг.) отражает рост/снижение динамики доли мигрантов на рынке труда и капитала в азиатском, африканском и латиноамериканском регионах (от 2,2 \% до 0,5 \%). Доля въезжающих в страны Европы и Северной Америки в 2019 г. сократилась по сравнению с 2000 г. (с 2,4\% до 1,6 \%). В период с 1990 г. по 2000 г. численность международных мигрантов в европейских государствах оставалась стабильной (более 32,0\%), тем временем - количество выезжающих в североамериканские страны за аналогичный период увеличивалось - с 18,0 \% до 23,2 \%. При этом, в анализируемом периоде устойчивы параметры доли присутствующих международных мигрантов в Океании (на уровне не менее 3,0 \%) (табл. 3) [International migrant stock 2019... web].

Таким образом, обращение к открытым данным Отдела народонаселения ООН позволило нам обобщить статистическую информацию, отражающую масштабы, направления, структуру миграционных процессов в мире.

Обзор научной литературы и теоретическая модель исследования. В настоящее время отечественные и иностранные специалисты, принимая во внимание информацию по статистике миграционных потоков (в том числе в ретроспективе) ООН, дополняют проблематику переселений содержательным анализом социальной динамики как

\section{Соотношение количества иммигрантов и общей численности населения}

\section{Таблица 1} в мире на середину года, 1990, 2000, 2019 гг.

\begin{tabular}{|l|c|c|c|}
\hline & 1990 г. & $\mathbf{2 0 0 0}$ г. & 2019 г. \\
\hline Общая численности населения в мире & $\mathbf{5 3 2 7 2 3 1 0 6 1}$ & $\mathbf{6 1 4 3 4 9 3 8 2 3}$ & $\mathbf{7 7 1 3 4 6 8 1 0 0}$ \\
\hline $\begin{array}{l}\text { Общее количество международных ми- } \\
\text { грантов на середину года }\end{array}$ & $\mathbf{1 5 3 0 1 1 4 7 3}$ & $\mathbf{1 7 3 5 8 8} 441$ & $\mathbf{2 7 1 6 4 2} 105$ \\
\hline $\begin{array}{l}\text { Доля мигрантов на середину года в \% от } \\
\text { общей численности населения мира }\end{array}$ & $\mathbf{2 , 9}$ & $\mathbf{2 , 8}$ & $\mathbf{3 , 5}$ \\
\hline
\end{tabular}

Таблица 2

Численность и доля международных мигрантов на середину года в разбивке по полу, 1990, 2000, 2019 гг.

\begin{tabular}{|c|c|c|c|c|c|}
\hline \multirow{2}{*}{ Год } & \multirow{2}{*}{$\begin{array}{c}\text { Общее количество } \\
\text { мигрантов на сере- }\end{array}$} & $\begin{array}{c}\text { Общее количество } \\
\text { дину года, млн чел. }\end{array}$ & $\begin{array}{c}\text { Доля на середину } \\
\text { мледину года, } \\
\text { года от общего коли- } \\
\text { чества мигрантов, \% }\end{array}$ & $\begin{array}{c}\text { Общее количество } \\
\text { на середину года, } \\
\text { млн чел. }\end{array}$ & $\begin{array}{c}\text { Доля на середину от общего коли- } \\
\text { чества мигрантов, \% }\end{array}$ \\
\hline 1990 & 153011473 & 77661689 & 50,8 & 75349784 & 49,2 \\
\hline 2000 & 173588441 & 88029221 & 50,7 & 85559220 & 49,3 \\
\hline 2019 & 271642105 & 141488004 & 52,1 & 130154101 & 47,9 \\
\hline
\end{tabular}


собственно процесса миграции, так и поведенческих стратегий мигрантов.

Роль международной миграции, тенденции развития и влияния миграционных процессов в условиях глобализации приведены в работах Багреева Е.Г., Богданова А.В., Егорова С.А., Малюченко А.А., Мартыненко В.В., Мартыненко С.В., Минича Д.С., Нехороших И.Н., Катыхина А.И., Хазова Е.Н. [Багреева, Минич 2018; Богданов, Егоров, Хазов 2020; Мартыненко, Мартыненко 2015; Нехороших, Катыхин 2020]. Анализ перемещений мигрантов в качестве детерминанты конфликтогенности представлен в исследованиях Бенхабиб С., Закалюкина Е.В. [Бенхабиб 2003; Закалюкина 2012]. Вопросы управления международной миграцией поднимаются Алешковским И.А., Ионцевым В.А., тогда как Малюченко А.А. акцентирует исследовательский интерес на состоянии миграционной проблематики в России [Алешковский, Ионцев 2015; Малюченко 2015]. Росту неопределенности среды и вызванной в связи с этим активизацией адаптационных процессов уделено внимание в статьях Мозговой А.В., Поповой И.В. и их соавторов [Мозговая, Шлыкова 2019; Попова, Гаджигасанова, Дудина 2020]. Тенденции и критерии, влияющие на представления принимающего сообщества о мигрантах в общероссийском и региональном аспектах (Ярославской обла- сти) охарактеризованы в издании Аналитического центра Ю. Левады, исследовании Гаджигасановой Н.С. [Общественное мнение... web; Гаджигасанова, Дудина 2014].

Мартыненко В.В., Мартыненко С.В. рассматривают миграционные процессы как одно из проявлений глобализации, которая способствует в определенной степени росту уровня интеграции человечества, и одновременно содержит риск и вероятность неуправляемой социально-политической дезинтеграции [Мартыненко, Мартыненко 2015, 48]. Вместе с тем, глобализация миграции в течение ряда десятилетий сопровождается нарастающей эскалацией миграционной взаимозависимости трудоизбыточных и трудонедостаточных регионов [Цапенко web].

Таким образом, государства могут быть одновременно представлены с двух сторон выступать и как страна-донор, и как странареципиент (например, США - донор для Канады и реципиент из стран Южной Америки). Исторически районы притяжения мигрантов поэтапно сменяются ранее неизвестными миграционными «коридорами», а усиливающаяся миграционная активность обусловлена глобализацией торговли, увеличением транспортных потоков и трансформацией коммуникационных технологий. Высококвалифицированные специалисты принимают решение о переезде (зачастую с семьей) в ответ на предложение о

Таблица 3

Численность международных мигрантов на середину года в разбивке по основным регионам, 1990, 2000, 2019 гг.

\begin{tabular}{|c|c|c|c|c|c|c|}
\hline \multirow[b]{2}{*}{ Регионы } & \multicolumn{2}{|c|}{1990 г. } & \multicolumn{2}{|c|}{2000 г. } & \multicolumn{2}{|c|}{2019 г. } \\
\hline & $\begin{array}{c}\text { Численность } \\
\text { международ- } \\
\text { ных мигрантов } \\
\text { на середину } \\
\text { года, } \\
\text { млн чел. }\end{array}$ & $\begin{array}{c}\text { Доля мигран- } \\
\text { тов на середи- } \\
\text { ну года } \\
\text { в \% от общей } \\
\text { численности } \\
\text { международ- } \\
\text { ных мигрантов }\end{array}$ & $\begin{array}{c}\text { Численность } \\
\text { международ- } \\
\text { ных мигрантов } \\
\text { на середину } \\
\text { года, } \\
\text { млн чел. }\end{array}$ & $\begin{array}{c}\text { Доля мигран- } \\
\text { тов на середи- } \\
\text { ну года } \\
\text { в \% от общей } \\
\text { численности } \\
\text { международ- } \\
\text { ных мигрантов }\end{array}$ & $\begin{array}{c}\text { Численность } \\
\text { международ- } \\
\text { ных мигрантов } \\
\text { на середину } \\
\text { года, } \\
\text { млн чел. }\end{array}$ & $\begin{array}{c}\text { Доля мигран- } \\
\text { тов на середи- } \\
\text { ну года в \% от } \\
\text { общей числен- } \\
\text { ности между- } \\
\text { народных ми- } \\
\text { грантов } \\
\end{array}$ \\
\hline Африка & 15689666 & 10,3 & 15051677 & 8,7 & 26529334 & 9,8 \\
\hline Азия & 48209949 & 31,5 & 49394322 & 28,5 & 83559197 & 30,7 \\
\hline Европа & 49608231 & 32,4 & 56858788 & 32,7 & 82304539 & 30,3 \\
\hline $\begin{array}{l}\text { Латинская } \\
\text { Америка } \\
\text { и Карибский } \\
\text { бассейн }\end{array}$ & 7161371 & 4,7 & 6570729 & 3,8 & 11673288 & 4,3 \\
\hline $\begin{array}{l}\text { Северная } \\
\text { Америка }\end{array}$ & 27610408 & 18,0 & 40351694 & 23,2 & 58647822 & 21,6 \\
\hline $\begin{array}{l}\text { Океания } \\
\text { (Австралия) }\end{array}$ & 4731848 & 3,1 & 5361231 & 3,1 & 8927925 & 3,3 \\
\hline Итого & 153011473 & 100,0 & 173588441 & 100,0 & 271642105 & 100,0 \\
\hline
\end{tabular}


повышении по должности в рамках деятельности транснациональных корпораций. В тоже время представители рабочих профессий мотивированы на миграцию для получения более высоких доходов и использования результатов благоприятной социальной политики принимающей страны.

В целом трудовые ресурсы вне зависимости от того, о высококвалифицированных специалистах либо рабочих кадрах идет речь, действительно оказывают влияние на интенсификацию экономики страны-приема мигрантов. Наряду с этим, как отмечают Нехороших И.Н. и Катыхин А.И., вложение инвестиций на фоне прироста совокупной численности населения приводит к мультипликативному эффекту в части формирования национальной экономики [Нехороших, Катыхин 2020, 93].

Миграция выступает катализатором не только экономических, но и преобразований, имеющих институциональный социокультурный характер (Хофстад Г. и Коэн А.). В частности, Багреева Е.Г., Минич Д.С. отмечают, что людям сложно разорвать связи со своей исконной культурой, а потому формируется конфронтация культур, что приводит к открытым столкновениям [Багреева, Минич 2018, 109]. В этом же ключе рассуждает о феномене разнообразия в глобальную эру Бенхабиб С., отмечая эффект «обратной глобализации», в ходе которой итогом масштабных миграций являются мультиэтничные и мультикультурные сообщества. В интересах достижения экономических целей в указанные сообщества желают быть включенными и представители мировой «периферии» [Бенхабиб 2003, 217].

Иноземцев В.А., последовательно анализируя работу Бенхабиб С., формулирует прогноз развития современной ситуации по следующим траекториям: ход культурной эволюции в одном случае характеризуется усилением мультикультурного взаимовлияния, а в другом - посредством стремления к институционализации, провоцирующее эскалацию разногласий в сфере межнационального общения, что становится объективным и в определенной степени неизбежным следствием интенсификации взаимодействий между представителями различных культур.

Вместе с тем, фиксируется и встречная амбивалентная ответная реакция в целом ряде стран-реципиентов - коренные жители защищают самобытную идентичность. Так, Багреева Е.Г., Минич Д.С. описывают кейсы в Гамбурге (Германия): негативный отклик общественности на контент плаката детского дошкольного учреждения, привлекательной особенностью которого позиционировалось «малое число детей из семей мигрантов», обязал руководство переиздать рекламный буклет. После принятых мер, в числе преимуществ появилась фраза: «Наш детский сад открыт для девочек и мальчиков, ...больных и здоровых, - независимо от того, немецкого они происхождения или из семей мигрантов» [Багреева, Минич 2018, 110]. Данный наглядный пример отступления от стратегии дискриминации в стране-приема иммигрантов - зачастую единичный случай, а не закономерность.

Принимая во внимание многообразие оценок специалистов, нами разработана теоретическая многофункциональная модель оценки перспектив международной миграции. Перспективы дальнейших разработок автор видит в более детальном изучении положения и ценностных ориентаций мигрантов разных поколений (в том числе на национальных рынках труда), а также специфику их взаимодействия с представителями принимающих сообществ с учетом не только глобализационных процессов, но под влиянием регионализации и определенного стремления к сохранению национальной идентичности. При этом, совершенно новой переменной в принимающем сообществе выступает оценка состояния неопределенности и наличие суженного горизонта планирования (рис. 1).

Вместе с тем, угроза реализации конфликтогенной ситуации в социокультурном взаимодействии принимающей стороны и прибывающих иностранных граждан (как представителей инокультурной среды) требует комплексной реализации программ взаимной адаптации вышеназванных акторов, а в качестве равноправных партнеров необходимо согласованное участие государственные структур и некоммерческих организаций. Тем самым, в адаптационные процессы должны быть вовлечены не только те, кто сменяет место жительства, но и те, кто принимает новых участников в свои локальные сообщества (то есть 


\section{СОЦИОЛОГИЯ И СОЦИАЛЬНЫЕ ТЕХНОЛОГИИ}

коренное население) [Гаджигасанова, Дудина 2014, 210]. Более того, представители принимающего сообщества также нуждаются в адаптации, особенно в ситуациях, характеризующихся как неопределенные, которые повсеместно утрачивают свойства чрезвычайности и становятся неотъемлемым явлением повседневности [Мозговая, Шлыкова 2019, 125; Попова, Гаджигасанова, Дудина 2020, 29].

Эмпирическая база: результаты и обсуждения. Поведенческие стратегии принимающей стороны и процесс взаимодействия принимающего сообщества с мигрантами можно смоделировать по результатам общероссийских и регионального эмпирических исследований, раскрывающих особенности взаимоотношений местных жителей (в стране приема) с мигрантами представителями инокультурной среды. Согласно общероссийскому исследованию общественного мнения Аналитического центра Ю. Левады ( $\mathrm{N}=1600$, 2019 г.), в числе первоочередных задач в социальной сфере наряду с такими задачами как введение мер по нивелированию резкого расслоения богатых и бедных (30,0\% ответов), осуществление деятельности по повышению доступности медицинского обслуживания $(30,0 \%)$, сглаживание роста платного образования $(22,0 \%)$ отмечается необходимость мер, направленных на сдерживание роста притока внешних мигрантов (18,0 \%). Это свидетельствует о недоброжелательном отношении части россиян к трудовым мигрантам. Также наблюдается увеличение сторонников тезиса «Нужно ограничивать приток трудовых мигрантов» - с 58,0 \% в июле 2017 г. до 72,0 \% в августе 2019 г. [Общественное мнение... web].

На этом фоне, сравнительный анализ социологических данных всероссийских исследований за период с 2013 по 2019 гг., показывает направленность взаимодействий местного сообщества с мигрантами, позволяет отметить двойственные проявления характера межгрупповых взаимоотношений. Так, среди россиян доля сторонников суждения «работа мигрантов вносит конструктивный вклад в развитие страны-приема и общества» остается стабильной - на уровне не менее $1 / 3$ (трети) ответов $(40,0 \%)$. Вместе с тем, существенно преобладают в российской среде и две принципиально противоположные установки: с одной стороны $-2 / 3$ участников опроса, поддерживают тезис о том, что родные и знакомые не откажутся выполнять работу, которую в данный момент выполняют иностранные граждане (64,0 \%), а с другой выделяется 63,0\% сторонников идеи «при-

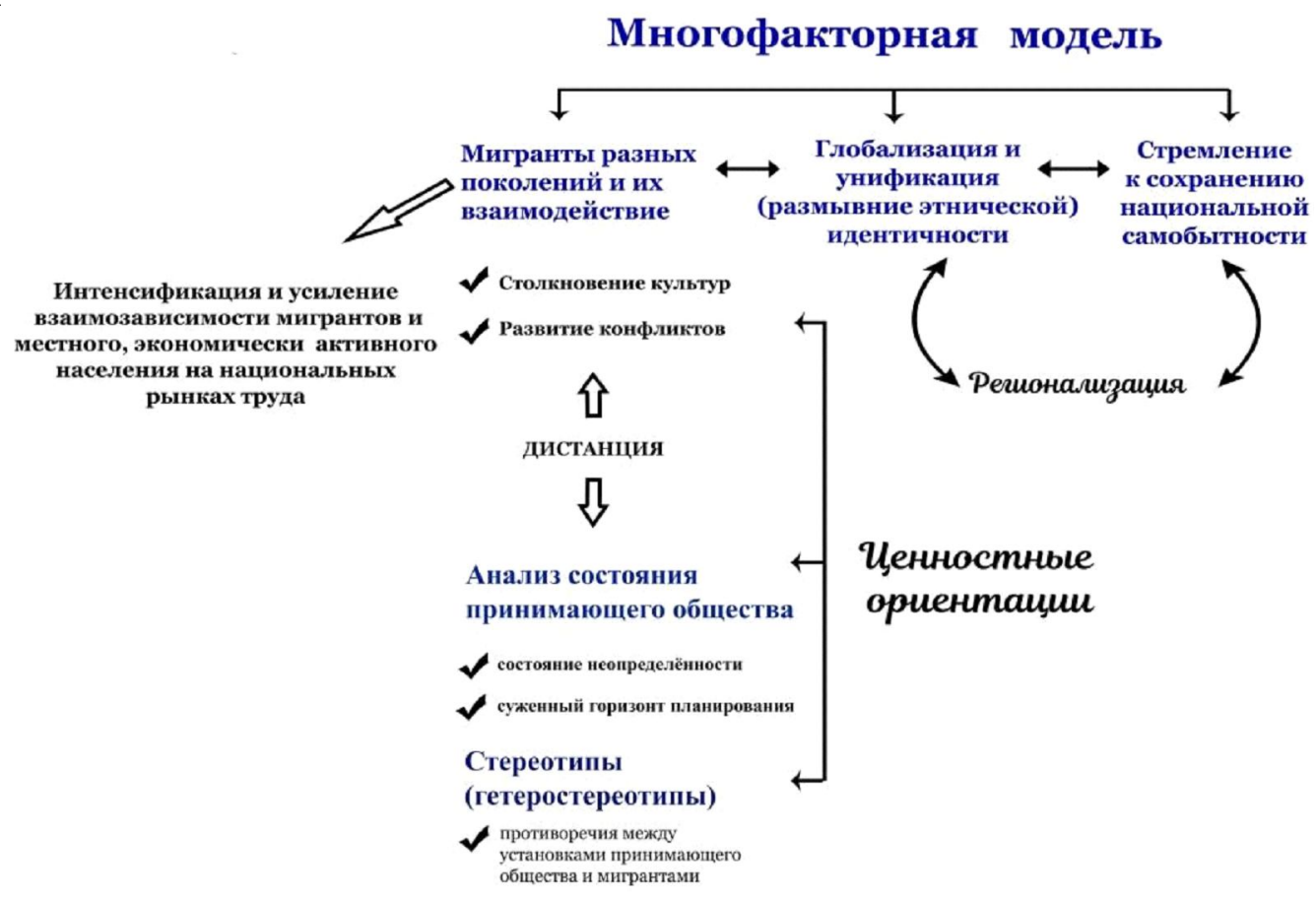

Рис. 1. Теоретическая многофункциональная модель оценки перспектив международной миграции 
сутствие мигрантов на локальном уровне в количественном выражении избыточно». Таким образом, фактором, который активизирует неконструктивные оценки во взаимодействиях между местными локальными сообществами и внешними группами приезжих может быть конструкт «угрозы», вызванный конкуренцией за ограниченные ресурсы. В этой связи, довольно предсказуема реакция, что чем более неустойчива, неопределенна экономическая ситуация в стране, чем ниже уровень заработной платы, тем чаще коренные жители будут рассматривать представителей внешней инокультурной среды как угрозу на рынке труда (табл. 4).

При этом, в ходе опросов 2013-2019 гг. каждый третий либо четвертый среднестатистический россиянин отмечает, что существенного прироста по миграционному потоку в течении последних лет в России не фиксируется. Подтверждением этому являются и общероссийские статистические данные, представленные в «Информации о социальноэкономическом положении России в 2020 г.», из которой следует, что за январь - авгусm 2020 г. миграционный прирост населения России сократился на 97,6 тыс. человек (на $58,5 \%$ ), что произошло в результате уменьшения числа прибывших в РФ и приумножения количества выбывших за пределы страны. Число прибывших в страну сократилось на 50,4 тыс. человек (на $11,7 \%$ ) в том числе за счет иммигрантов из государств-участни- ков СНГ на 39,7 тыс. человек (на 10,3 \%). Число выбывших за пределы России выросло на 47,2 тыс. человек (на $17,9 \%$ ), в том числе в страны государства-участники СНГ - на 37,3 тыс. человек (на 15,8 \%). В январе - августе 2020 г. в обмене населением со всеми государствами-участниками СНГ, кроме как с гражданами Украины, отмечается сокращение миграционного прироста [Информация о социально-экономическом... web].

Протестный контекст в отношении приема иммигрантов в нашей стране сохраняется и в результатах региональных исследований, проводимых под руководством автора данной статьи. Так, согласно научно-исследовательскому проекту «Отношение к мигрантам со стороны принимающего населения» (Ярославская область, $N=614,2020$ г.), среди участников опроса 44,0 \% не согласны с суждением, что иммиграция оказывает положительное воздействие на экономическую сферу, тогда как 30,0 \% респондентов выбирают вариант «мне все равно». Амбивалентное отношение сформировалось к присутствию мигрантов на российском рынке труда: с одной стороны, более половины опрошенных отмечают, что иммигранты «лишают» рабочих мест местных жителей, в какой-то степени оказывая влияние на снижение средней заработной платы (64,0 \% ответов), а с другой более $1 / 3$ жителей региона склонны согласиться, что иностранные приезжие компенсируют недостаточное количество трудовых ресурсов

Таблича 4

Данные общероссийских исследований общественного мнения Аналитического центра Ю. Левады $(n=1600$, июнь 2013 г. - август 2019 г.)

\begin{tabular}{|c|c|c|c|c|c|c|}
\hline \multirow{3}{*}{ Суждение } & \multicolumn{6}{|c|}{ Градации переменной } \\
\hline & \multicolumn{2}{|c|}{$\begin{array}{l}\text { определенно, } \\
\text { да / скорее да }\end{array}$} & \multicolumn{2}{|c|}{$\begin{array}{c}\text { определенно, } \\
\text { нет / скорее нет }\end{array}$} & \multicolumn{2}{|c|}{ затрудняюсь ответить } \\
\hline & 06.2013 & 08.2019 & 06.2013 & 08.2019 & 06.2013 & 08.2019 \\
\hline $\begin{array}{lll}\text { Работа мигрантов полезна для } \\
\text { страны и общества }\end{array}$ & $41,0 \%$ & $47,0 \%$ & $51,0 \%$ & $46,0 \%$ & $8,0 \%$ & $7,0 \%$ \\
\hline $\begin{array}{l}\text { Присутствие иммигрантов в на- } \\
\text { шем населенном пункте / регионе } \\
\text { чрезмерно }\end{array}$ & $69,0 \%$ & $63,0 \%$ & $26,0 \%$ & $32,0 \%$ & $5,0 \%$ & $5,0 \%$ \\
\hline $\begin{array}{l}\text { Мои родные и знакомые не отка- } \\
\text { жутся выполнять работу, которую } \\
\text { сейчас выполняют иностранные } \\
\text { граждане }\end{array}$ & $57,0 \%$ & $64,0 \%$ & $27,0 \%$ & $29,0 \%$ & $16,0 \%$ & $7,0 \%$ \\
\hline $\begin{array}{l}\text { Большинство } \\
\text { лигрантов }\end{array}$ & - & $44,0 \%$ & - & $41,0 \%$ & - & $15,0 \%$ \\
\hline
\end{tabular}

Примечание. * - в 2013 г. данное суждение респондентам не предлагалось. 
в слабоквалифицированных, малооплачиваемых отраслях экономики (44,0 \%). Также сохраняются устойчивые стереотипные установки: подавляющее большинство убеждены, что поведенческие стратегии иммигрантов в той либо иной степени оказывает влияние на ухудшение статистических показателей по криминогенной обстановке, коррупции (70,0 \%) (табл. 5).

Вместе с тем, отвечая на вопрос о содержании взаимоотношений между приезжими (представителями инокультурной среды) и местными жителями в населенном пункте их проживания, практически $2 / 3$ респондентов характеризуют взаимодействия данных социальных групп как «спокойные» $(68,4$ \%), тогда как $1 / 5$ жителей Ярославской области отмечают, что атмосфера отношений в локальном социальном пространстве напряженная
$(21,8$ \%). При этом, участники опроса фиксируют, что практика привлечения внешних мигрантов распространена в сферах торговли и жилищно-коммунального хозяйства $-91,8 \%$ и $78,3 \%$ соответственно, а также в строительстве $(70,3 \%)$ и в общественном питании $(69,2 \%)$. В тоже время, частичное присутствие внешних мигрантов жители региона отмечают в области здравоохранения $(35,7 \%$ ответов) и в сфере обслуживания общественного транспорта $(33,6 \%)$, тогда как в большинстве своем отсутствует привлечение приезжих в обеспечение деятельности органов местного самоуправления $(73,6 \%$ ответов «практически не распространена»), системы образования $(68,3 \%)$, финансового сектора экономики $(68,0 \%)$ либо на службу в правоохранительные органы (53,8 \%) (табл. 6).

Таблииа 5

Распределение ответов на вопрос: «Какова степень Вашего согласия либо не согласия с предложенными утверждениями?» (Ярославская область, $N=614,2020$ г.)

\begin{tabular}{|l|c|c|c|}
\hline \multicolumn{1}{|c|}{ Суждение } & \multicolumn{3}{|c|}{ Градации переменной } \\
\cline { 2 - 4 } & $\begin{array}{c}\text { абсолютно согласен / } \\
\text { скорее согласен }\end{array}$ & мне все равно & $\begin{array}{c}\text { абсолютно не согласен / } \\
\text { скорее не согласен }\end{array}$ \\
\hline $\begin{array}{l}\text { Иммиграция оказывает положительное воз- } \\
\text { действие на экономическую сферу }\end{array}$ & $26,0 \%$ & $30,0 \%$ & $44,0 \%$ \\
\hline $\begin{array}{l}\text { Иммигранты влияют на ухудшение показа- } \\
\text { телей по криминогенной обстановке, кор- } \\
\text { рупции }\end{array}$ & $70,0 \%$ & $22,0 \%$ & $8,0 \%$ \\
\hline $\begin{array}{l}\text { Иммигранты «лишают» рабочих мест мест- } \\
\text { ных жителей, «сбивают» среднюю заработ- } \\
\text { ную плату }\end{array}$ & $64,0 \%$ & $30,0 \%$ & $6,0 \%$ \\
\hline $\begin{array}{l}\text { Иммигранты компенсируют дефицит трудо- } \\
\text { вых ресурсов в слабоквалифицированных, } \\
\text { малооплачиваемых отраслях экономики }\end{array}$ & $44,0 \%$ & $40,0 \%$ & $16,0 \%$ \\
\hline
\end{tabular}

Таблица 6

Распределение ответов на вопрос: «По Вашему опыту, в каких сферах экономики Ярославской области в наибольшей степени распространена практика привлечения внешних мигрантов?»

\begin{tabular}{|c|c|c|c|c|}
\hline \multirow[b]{2}{*}{ Сферы экономики } & \multicolumn{4}{|c|}{ Градации переменной } \\
\hline & $\begin{array}{c}\text { иироко } \\
\text { распространена }\end{array}$ & $\begin{array}{c}\text { распространена } \\
\text { частично }\end{array}$ & $\begin{array}{c}\text { практически } \\
\text { не распространена }\end{array}$ & $\begin{array}{c}\text { затрудняюсь } \\
\text { ответить }\end{array}$ \\
\hline Рынок, сфера торговли & $91,8 \%$ & $8,2 \%$ & - & - \\
\hline Общественное питание & $69,2 \%$ & $21,7 \%$ & $9,1 \%$ & - \\
\hline Общественный транспорт & $49,1 \%$ & $33,6 \%$ & $17,0 \%$ & - \\
\hline Бизнес, финансы & $10,3 \%$ & $11,5 \%$ & $68,0 \%$ & $10,2 \%$ \\
\hline Жилищно-коммунальное хозяйство & $78,3 \%$ & $19,8 \%$ & - & $1,9 \%$ \\
\hline $\begin{array}{l}\text { Органы местной власти, } \\
\text { самоуправления }\end{array}$ & $2,2 \%$ & $6,2 \%$ & $73,6 \%$ & $18,0 \%$ \\
\hline Правоохранительные органы & $3,9 \%$ & $16,2 \%$ & $53,8 \%$ & $26,1 \%$ \\
\hline Строительство, промышленность & $70,3 \%$ & $20,4 \%$ & $5,7 \%$ & $3,6 \%$ \\
\hline Медицина & - & $35,7 \%$ & $44,5 \%$ & $19,8 \%$ \\
\hline Образование, наука & - & $9,6 \%$ & $68,3 \%$ & $22,1 \%$ \\
\hline
\end{tabular}


Выводы и заключение. В процессе работы выявлено, что в мире отчетливо фиксируется тенденция к увеличению доли международных мигрантов (с 2,8 \% до 3,5 \%); трансформируется структура миграционных перемещений в региональном разрезе: доля присутствия иностранных приезжих в азиатском, африканском и латиноамериканском регионах характеризуется неустойчивыми колебаниями в направлении прироста либо сокращения, в то время как доля въезжающих в страны Европы и Северной Америки сократилась в 2019 г. по сравнению с 2000 г. В целом, имеет место интенсивная горизонтальная мобильность, в результате которой происходит непропорциональная миграция населения из одних регионов в другие, при этом без привязки к уровню развития стран.

Миграционные процессы являются несомненным атрибутом современной глобализации, имеют как объединяющие, так и разъединяющие последствия. Международные перемещения сопряжены с существенным ростом транспортных потоков, интенсификацией коммуникационных технологий, на фоне которых изменяются регионы, первоначально испытывавшие недостаток трудовых ресурсов, и регионы с избытком рабочей силы. Вместе с тем, в конкуренцию за кадры, обладающие высокой квалификацией все активнее включаются транснациональные корпорации, тогда как мигранты рабочих специальностей делают выбор страны-реципиента на основе данных о политике социальной защиты и обеспечения (преимущественно в пользу западноевропейских, скандинавских стран). Исходя из этого, в демократических государствах наблюдается диверсификация механизма социальной защиты, проявляющееся в формировании запроса на обеспечение гарантированной коллективной защиты в отношении обладателей статуса «гражданина» и «не гражданина».

Наряду с этим, масштабные миграции сопровождает формирование мультиэтнических сообществ, в число которых включаются и представители мировой «периферии». В самих мультикультурных сообществах параллельно отмечается наличие двух составляющих: с одной стороны - усиление межкультурного взаимодействия, с другой - кон- фликтные стороны взаимодействия. Указанные тренды в ряде исследовательских работ анализируются в качестве эффекта «обратной глобализации». Востребованность разработки двусторонних адаптационных программ продиктована повышенной вероятностью реализации конфликтогенной составляющей в социокультурном взаимодействии граждан принимающей страны с внешними мигрантами.

Амбивалентное реагирование на современные миграционные процессы со стороны правительства, жителей страны-приема становится повседневной практикой. Результаты общероссийских и региональных исследований (проведенных в том числе и автором) зафиксировали активизацию защитной реакции со стороны локальных сообществ в ответ на приток иностранных граждан. В связи с этим, растут риски, связанные с формированием непреодолимых, трудноразрешимых противоречий и неравенства, дифференцирующие статусы гражданина и негражданина в рыночной экономической системе. Таким образом, с одной стороны - государственные границы интенсивно раздвигаются, а с другой - мигранты часто локализуются и минимально взаимодействуют с местным сообществом, поэтому возрастает актуальность изучения специфики межгрупповых отношений и взаимодействий, особенностей формирования запросов и потребностей не только принимающих сообществ, но и мигрантов в конкретных регионах.

\section{СПИСОК ЛИТЕРАТУРЫ}

Алешковский, Ионцев 2015 - Алешковский И.А., Ионцев B.A. Управление международной миграцией в условиях глобализации // Век глобализации. 2015. № 1. С. 75-87.

Багреева, Минич 2018 - Багреева Е.Г., Минич Д.С. Институциональные тенденции влияния миграционных процессов // Политика и экономика Евразии. 2018. № 6 (37). С. 107-112.

Бенхабиб 2003 - Бенхабиб С. Притязания культуры. Равенство и разнообразие в глобальную эру / пер. с англ.; под ред. В.И. Иноземцева. М.: Логос, 2003.

Богданов, Егоров, Хазов 2020 - Богданов А.В., Егоров С.А., Хазов Е.Н. Миграционные процес- 
сы и их роль глобализации общества // Международный журнал конституционного и государственного права. № 1/2020. С. 12-19.

Гаджигасанова, Дудина 2014 - Гаджигасанова Н.С., Дудина И.М. Тенденции и критерии, влияющие на представления принимающего сообщества о мигрантах на региональном уровне // Малочисленные этносы в пространстве доминирующего общества: практика прикладных исследований и эффективные инструменты этнической политики: сб. науч. ст. по итогам всерос. с междунар. участием науч.-практ. конф. (г. Кемерово, 17-18 окт. 2014 г.) / отв. ред. В.В. Поддубиков. Кемерово: Практика, 2014. С. 209-214.

Закалюкина 2012 - Закалюкина E.B. Миграция как фактор конфликтогенности в условиях глобализации // Региональное образование XXI века: проблемы и перспективы. 2012. № 3. C. $90-92$.

Информация о социально-экономическом... web Информация о социально-экономическом положении России: Январь - сентябрь 2020 г. Демография. М.: Федеральная служба государственной статистики (Росстат) // https:// rosstat.gov.ru/compendium/document/50800.

Малюченко 2015 - Малюченко А.А. Проблема миграции населения в России в условиях глобализации // Актуальные проблемы авиации и космонавтики. 2015. Т. 2. С. 579-581.

Мартыненко, Мартыненко 2015 - Мартыненко В.В., Мартыненко C.В. Международная миграция, миграционная политика и глобальное развитие // Вестн. Моск. ун-та. Серия 12, Политические науки. 2015. № 3. С. 44-55.

Мозговая, Шлыкова 2019 - Мозговая А.В., Шлькова E.B. Адаптация к неопределенности среды: ресурсы жителей больших городов // Logos et Praxis. 2019. T. 18, № 3. C. 124-130.

Нехороших, Катыхин 2020 - Нехороших И.Н., Катыхин А.И. Международная/миграция,/тенденции/развития // Регион: системы, экономика, управление. 2020. № 2 (49). С. 90-96.

Общественное мнение... web - Общественное мнение - 2019 (сборник). М.: Левада-Центр, 2020 // https://www.levada.ru/sbornik-obshhestvennoemnenie/obshhestvennoe-mnenie-2019.

Попова, Гаджигасанова, Дудина 2020 - Попова И.В., Гаджигасанова Н.С., Дудина И.М. Влияние уровня неопределенности и трансформации социальной среды на формирование кредитного поведения населения // Известия высших учебных заведений. Социология. Экономика. Политика. 2020. № 1. С. 24-31.

Цапенко web - Цапенко И.П. Регионализация миграционных процессов // Контуры глобальных трансформаций: политика, экономика, право. 2017. T. 10, № 4 // https://cyberleninka.ru/ article/n/regionalizatsiya-migratsionnyhprotsessov.

International migrant stock $2019 \ldots$ web - International migrant stock 2019/United Nations; Departament of Ekonomic and Social Affairs Population Division; International Migration // https:// www.un.org/en/development/desa/population/ migration/data/estimates2/estimates19.asp.

Total number of international... web - Total number of international migrants at mid-year 2019 / MIGRATION DATA PORTAL. The bigger picture // https://migrationdataportal.org.

\section{REFERENCES}

Aleshkovsky I.A., Iontsev V.A., 2015. Management of international migration in the context of globalization. Vek globalizatsii, no 1, pp. 75-87.

Bagreeva E.G., Minich D.S., 2018. Institutional trends of migration processes influence. Politika $i$ ekonomika Yevrazii, no. 6(37), pp. 107-112.

Benhabib S., 2003. The claims of culture. Equality and Diversity in the Global Era. V.I. Inozemtsev (ed.) Moscow, Logos.

Bogdanov A.V., Egorov S.A., Khazov E.N., 2020. Migration processes and their role in the globalization of society. Mezhdunarodnyy zhurnal konstitutsionnogo i gosudarstvennogo prava, no. 1, pp. 12-19.

Gadzhigasanova N.S., Dudina I.M., 2014. Trends and Criteria Influencing Host Community Perceptions of Migrants at the Regional Level. Poddubikov V.V. (ed.) Malochislennyye etnosy $v$ prostranstve dominiruyushchego obshchestva: praktika prikladnykh issledovaniy i effektivnyye instrumenty etnicheskoy politiki: sb. nauch. st. po itogam vseros. s mezhdunar. uchastiyem nauch.-prakt. konf., Kemerovo, 17-18 oktyabrya 2014. Kemerovo, Praktika Publ., pp. 209-214.

Zakalyukina E.V., 2012. Migration as a factor of conflict in the context of globalization. Regional'noye obrazovaniye XXI veka: problemy i perspektivy, no. 3. pp. 90-92.

Informatsiya o sotsial'no-ekonomicheskom polozhenii Rossii, 2020. Yanvar'- sentyabr'. Demografiya. Moscow, Federal'naya sluzhba gosudarstvennoy statistiki. URL: https:// rosstat.gov.ru/compendium/document/50800 (accessed 21 October 2020).

Malyuchenko A.A., 2015. The problem of population migration in Russia in the context of globalization. Aktual'nyye problemy aviatsii $i$ kosmonavtiki, vol. 2, pp. 579-581. 
Martynenko V.V., Martynenko S.V., 2015. International migration, migration policy and global development. Vestn. Mosk. un-ta. Ser. 12. Politicheskiye nauki, no 3, pp. 44-55.

Mozgovaya A.V., Shlykova E.V., 2019. Adaptation to the uncertainty of the environment: the resources of residents of large cities. Logos et Praxis, vol. 18, no. 3, pp. 124-130.

Nekhoroshikh I.N., Katykhin A.I. 2020. International migration, development trends. Region: sistemy, ekonomika, upravleniye, no. 2 (49), pp. 90-96.

Public Opinion - 2019 (sbornik). Moscow, LevadaCenter. URL: https://www.levada.ru/sbornikobshhestvennoe-mnenie/ (accessed 28 October 2020).

Popova I.V., Gadzhigasanova N.S., Dudina I.M., 2020. The influence of the level of uncertainty and transformation of the social environment on the formation of credit behavior of the population.
Izvestiya vysshikh uchebnykh zavedeniy. Sotsiologiya. Ekonomika. Politika, no. 1, pp. 24-31.

Tsapenko I.P., 2017. Regionalization of migration processes. Kontury global'nykh transformatsiy: politika, ekonomika, pravo, vol. 10, no. 4. URL: https:/cyberleninka.ru/article/n/regionalizatsiyamigratsionnyh-protsessov (accessed 14 August 2020).

International migrant stock 2019. United Nations. Departament of Ekonomic and Social Affairs Population Division. International Migration. URL: https://www.un.org/en/development/desa/ population/migration/data/estimates $2 /$ estimates 19.asp (accessed 20 October 2020).

Total number of international migrants by mid-2019, 2019. MIGRATION DATA PORTAL. The bigger picture. URL: https://migrationdataportal.org/ (accessed 25 September 2020).

\section{Information About the Author}

Naide S. Chernysheva, Candidate of Sciences (Sociology), Associate Professor, Department of Social Policy, P.G. Demidov Yaroslavl State University, Sovetskaya St, 10, 150000 Yaroslavl, Russian Federation, naide27@mail.ru, https://orcid.org/0000-0002-7112-8760

\section{Информация об авторе}

Наиде Сефтеровна Чернышева, кандидат социологических наук, доцент кафедры социальной политики, Ярославский государственный университет им. П.Г. Демидова, ул. Советская, 10, 150000 г. Ярославль, Российская Федерация, naide27@mail.ru, https://orcid.org/0000-0002-7112-8760 